\title{
On the occurrence and health risks of the Silver-cheeked Toadfish (Lagocephalus sceleratus Gmelin, 1789) in the marine ecosystem of the Gaza Strip, Palestine
}

\author{
ABDEL FATTAH N. ABD RABOU \\ Departments of Biology and Marine Sciences, Faculty of Science, Islamic University of Gaza. Gaza Strip, Palestine \\ email: arabou@iugaza.edu.ps
}

Manuscript received: 15 July 2019. Revision accepted: 23 August 2019.

\begin{abstract}
Abd Rabou AFN. 2019. On the occurrence and health risks of the Silver-cheeked Toadfish (Lagocephalus sceleratus Gmelin, 1789) in the marine ecosystem of the Gaza Strip, Palestine. Biodiversitas 20: 2620-2627. The Silver-cheeked Toadfish (Lagocephalus sceleratus Gmelin, 1789) is one of the most recent invaders into the Mediterranean Sea. It represents a serious ecological risk to Mediterranean biodiversity and fisheries resources and a health risk to public health. The current study comes to handle the occurrence and health risks of the species in the Eastern Mediterranean of the Gaza Strip, Palestine. Frequent visits to local fish markets, meetings, and discussions with stakeholders, and chasing of local media reports were the main tools involved to satisfy the goals of the study, which extended from 2010 to 2019. The first record of the Silver-cheeked Toadfish in the Mediterranean coast of the Gaza Strip was in 2006 as claimed by fisheries parties. The by-catch of the species by fishing gear extended over the entire length of the Mediterranean coast of the Gaza Strip (42 km). The species was said to damage fishing nets, lines and hooks by its strong teeth. Prior to its banning in early 2010s, all pufferfishes including the species in question were sold freely in Gaza fish markets. Several cases of hospitalization have been reported in the Gaza Strip after consumption of the Silver-cheeked Toadfish. The symptoms of TTX intoxication included nausea and vomiting, dizziness, headache, abdominal pain, perioral paraesthesia, and tingling over the entire body. No death cases were reported locally. Many awareness campaigns have been conducted by fisheries parties to warn both fishermen and local people from the ecological and health risks associated with the Silver-cheeked Toadfish and TTX intoxication. Finally, the threats imposed by the Silvercheeked Toadfish on the Eastern Mediterranean countries including Palestine indicate that potential solutions to the problem should be explored.
\end{abstract}

Keywords: Silver-cheeked Toadfish, Lagocephalus sceleratus, Mediterranean Sea, marine ecosystem, occurrence, risks, Gaza Strip

\section{INTRODUCTION}

The Mediterranean Sea is home to a wealth of native as well as numerous invasive (exotic or alien) marine species (Abdul Malak et al. 2011). In general, fish diversity of the Mediterranean Sea is known to decrease from west to east because of the effect of straits, various current systems, salinity level and temperature regime. The Mediterranean Sea seems to be one of the main hot spots of marine bioinvasions on Earth, because of the introductions reported (Rilov and Galil 2009; Abdul Malak et al. 2011). The routes of invasive or non-indigenous species include the Suez Canal, the Gibraltar Strait, ship ballast water and accidental release. The most important of which is the Suez Canal of Egypt, which was constructed in 1869 to connect between the Mediterranean and Red Seas. The Canal $(162.5 \mathrm{~km})$ provides a limited chance for Red Sea species to migrate to the Mediterranean Sea (Lessepsian migrants) and vice versa (anti-Lessepsian migrants). The number of Lessepsian migrants exceeds by far the number of antiLessepsian migrants (Cevik et al. 2002). Some of the Lessepsian migrants have been considered to be very successful colonizers of Mediterranean marine ecosystems (Golani 1996; Golani and Azzurro 2007). In this regard, Lessepsian migration is not only expected to continue but to increase in intensity as a result of the global climate change and the overall increase of seawater temperature that cause a poleward shift in species distribution. This phenomenon is now described as the tropicalization of temperate regions (Encarnação et al. 2019).

The relatively shallow water (around 10 meters) of the Suez Canal is considered as a major physical barrier for the migration of deep water species from the Indo-Western Pacific Oceans and the Red Sea. Accordingly, most of the invasive species can be found at depths of less than $70 \mathrm{~m}$ in the Eastern Mediterranean (Peristeraki et al. 2006). Such Lessepsian migrants impact negatively fisheries, biodiversity, and habitats of the Mediterranean Sea. In spite of its small area, the marine ecosystem of the Gaza Strip in the Mediterranean Sea is vulnerable to the adverse impacts of invasive species; particularly the aggressive predatory Silver-cheeked Toadfish (Lagocephalus sceleratus) (Abu Amra 2018), which was considered as one of the fastest expanding Lessepsian immigrants in the Mediterranean Sea up to now (Peristeraki 2006).

The Silver-cheeked Toadfish (Lagocephalus sceleratus Gmelin, 1789) is an extremely poisonous marine bony fish belonging to the Tetraodontidae family (pufferfishes). This Lessepsian species is common in the tropical waters of the Indo-Western Pacific Ocean. Nowadays, the fish is 
spreading at an alarming rate into the eastern and western Mediterranean, showing easy adaptability to invade new ecological marine habitats and ecosystems. The species was first recorded in 2003 in Gokova Bay of Turkey (Akyol et al. 2005). Soon afterwards, the species established abundant populations along the coasts of nearly, if not all, the Mediterranean countries (Akyol et al. 2005; Golani and Levy 2005; Golani and Azzurro 2007; Kasapidis et al. 2007; Rilov and Galil 2009; Türker-Çakır et al. 2009; EastMed 2010; Kalogirou et al. 2010; Halim and Rizkalla 2011; Torcu-Koç et al. 2011; Yaglioglu et al. 2011; Jribi and Bradai 2012; Milazzo et al. 2012; Nader et al. 2012; Başusta et al. 2013; Beköz et al. 2013; Kalogirou 2013; Azzurro et al. 2014; Ben Souissi et al. 2014; Dulčić et al. 2014; Sulić-Šprem et al. 2014; Tiralongo and Tibullo 2014; Tunçer and Önal 2014; Deidun et al. 2015; Irmak and Altınağaç 2015; Kara et al. 2015; El-Haweet et al. 2016; Akyol and Ünal 2017; Carbonara et al. 2017; Ünal and Göncüoğlu-Bodur 2017).

The Silver-cheeked Toadfish (Figure 1) is considered one of the "worst" biological invaders of the Mediterranean Sea (Nader et al. 2012). Although many species of pufferfishes are economically important and edible in many countries of the Mediterranean region, the Silver-cheeked Toadfish, in particular, is not among the commercial species because of its high toxicity. Therefore, it has been considered to be a serious hazard to consumers since it contains a strong and potent marine toxin called Tetrodotoxin (TTX), which can be very poisonous and even lethal to humans (Sims and Ostman, 1986; Ahasan et al. 2004; Zaki 2004; Bentur et al. 2008; Noguchi and Arakawa 2008; Saoudi et al. 2008; Chamandi et al. 2009; Katikou et al. 2009; Arakawa et al. 2010; Islam et al. 2011; Kheifets et al. 2012; Nader et al. 2012; Kosker et al. 2016; Tamele et al. 2019).

Many morphological and ecological characteristics in addition to feeding and reproduction biology aspects of the Silver-cheeked Toadfish were described by numerous studies (Sabrah et al. 2006; Rilov and Galil 2009; Kalogirou et al. 2010; Aydin 2011; Bariche 2012; Başusta et al. 2013; Kalogirou 2013; Rousou et al. 2014; Ali et al. 2015; El-Haweet et al. 2016; Carbonara et al. 2017). It has two strong teeth in each jaw which are capable of ripping and damaging fishing nets and longlines. The Silvercheeked Toadfish is carnivorous in the sense that it feeds on a diversity of vertebrate and invertebrate items including fishes, shrimps, crabs, squids, cuttlefish, and other mollusks. In the Mediterranean, the species are being caught as by-catch. Thus, it has no actual economic value and is therefore directly discarded at sea (EastMed 2010). A striking event was mentioned by Kleitou et al. (2018) who reported the incidence of a juvenile Silver-cheeked Toadfish predation by an adult Common Dolphinfish (Coryphaena hippurus) in the Mediterranean Sea. Such an event can potentially guide future management efforts of the invasive Silver-cheeked Toadfish control in the Mediterranean basin.

As shown in the previous paragraphs, the studies concerning the Lessepsian Silver-cheeked Toadfish and its adverse impacts on marine habitats and ecosystems, fisheries resources and public health are increasing day by day worldwide; particularly in the eastern Mediterranean basin. In the Gaza Strip, the studies concerning the species seem to be lacking. Abd Rabou et al. (2007) described the threats facing the marine environment in the Gaza Strip, of which the invasive or alien species were apart. Abd Rabou (2013) highlighted some of the ecological risks associated with the Lessepsian marine biota in the Mediterranean Sea. He paid attention to the importance of surveying the Lessepsian migrants on the marine ecosystem of the Gaza Strip.

Shaheen (2016) surveyed in his M.Sc. dissertation, supervised by the author, the main fishes cultured in the Gaza Strip. He gave a secondary list on many marine bony fishes existing at the marine ecosystem of the Gaza Strip, of which the Half-smooth Golden Pufferfish (Lagocephalus spadiceus) is an example. More recently, Abu Amra (2018) surveyed in her M.Sc. dissertation, supervised by the author too, the marine bony fishes of the Mediterranean coast of the Gaza Strip. She recorded as many as 128 bony fish species belonging to 56 families and 15 orders, of which $30.47 \%$ were exotic and seem to be Lessepsian migrants. She added that many poisonous and dangerous species were caught and sold at the fish markets of the Gaza Strip, with the Silver-cheeked Toadfish was a striking example. Accordingly, the current study aims at increasing the knowledge on the occurrence and health risks of the Silver-cheeked Toadfish in the Gaza Strip (Eastern Mediterranean). The significance of this study comes from the fact that it is the first of its kind dealing with the dangerous Silver-cheeked Toadfish in the Gaza Strip.

\section{MATERIALS AND METHODS}

\section{The Gaza Strip}

The Gaza Strip $\left(31^{\circ} 25^{\prime} \mathrm{N}, 34^{\circ} 20^{\prime} \mathrm{E}\right)$ is an arid strip of the Palestinian land along the southeastern Mediterranean, having an area of $365 \mathrm{~km}^{2}$, and a population of about 2.0 million, of whom the majority are United Nationsregistered refugees. The Gaza Strip is one of the most densely populated places in the world. With regard to fisheries, the Gaza Strip has a total number of 3,500 fishermen working on more than 800 fishing vessels of different sizes and capacities. The total production of fisheries resources is about 3,480 tons per year. The fishing area is changeable and the accessibility and exploitation of Gazan fishermen to the very limited fishing area is often governed by Israel. The Directorate General of Fisheries, Ministry of Agriculture, is the competent, responsible and authorized authority to ensure the maximum utilization of fishery resources in the Palestinian Territories. Tens of people are working on fisheries resources in the Ministry of Agriculture. More than half of those people are scientists in agricultural disciplines including aquaculture and marine biology. 


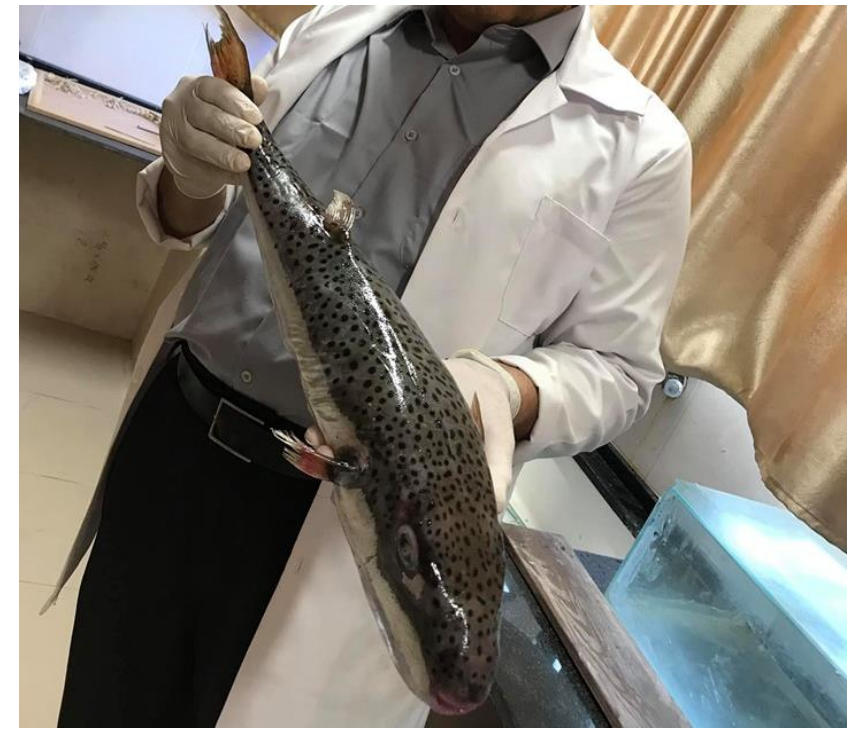

Figure 1. A Lagocephalus sceleratus specimen, recently caught from the Mediterranean coast of the Gaza Strip, Palestine

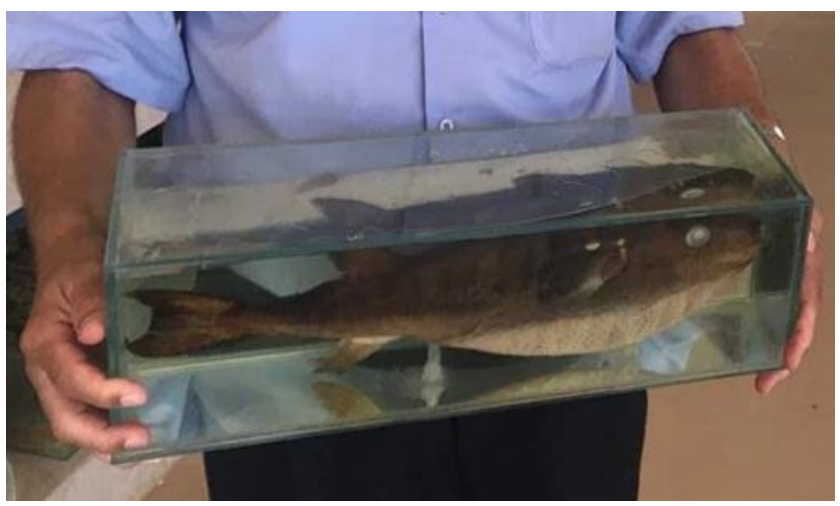

Figure 2. A formalin-preserved specimen of Lagocephalus sceleratus, encountered at the museum of the Directorate General of Fisheries, Ministry of Agriculture, Gaza Strip, Palestine

\section{Procedure}

The current study is a cumulative in its style, extending from 2010 to 2019. During the study period, tens of visits have been carried out in the early morning hours to the "Hesba" and auction or "Dalala" markets which are the main fish markets of the Gaza City. The two markets lie close to the Gaza fishing port where most catch landings are taking place. It is worth mentioning that a mix of bony, cartilaginous and invertebrate fish species is commonly traded at the places in question. Irregular visits have been carried out to the fish markets of the Gaza and North Gaza Governorates of the Gaza Strip as well.

Meetings and discussions with Gazan fishermen and the staff of the Directorate General of Fisheries, Ministry of Agriculture have been carried out to fill the gaps needed in data collection concerning the occurrence and toxicity of Lagocephalus sceleratus in the Gaza Strip. The museums of the Directorate General of Fisheries, Ministry of
Agriculture and the Biology Departments of the local universities were reached as well to investigate the preserved fish specimens (Figure 2). Local media reports regarding the species have been chased by the author as well to collect additional data on the occurrence and health risks of the Silver-cheeked Toadfish in the Gaza Strip. Finally, professional digital cameras have been used throughout the study period and photos were taken for documentary and confirmatory purposes.

\section{RESULTS AND DISCUSSION}

\section{First record and morphometric measurements of the Silver-cheeked Toadfish in the Gaza Strip}

As far as the Silver-cheeked Toadfish is concerned, all local fisheries parties confirmed that the first record of the species in the Mediterranean waters of the Gaza Strip, Palestine was in 2006; which means three years after its first record in 2003 in Gokova Bay of Turkey (Akyol et al. 2005). Nowadays, the species has been caught off the coasts of nearly all Mediterranean countries as pointed out by many authors (Golani and Levy 2005; Nader et al. 2012; Alshawy et al. 2019). Local morphometric measurements of a single sample of the Silver-cheeked Toadfish caught in the Mediterranean waters of the Gaza city, Gaza Strip in 2019 were done using a measuring board (Table 1). The relative proportions of the species as shown in Table 1 seem to correspond to those reported by many studies for specimens recorded from the Red and Mediterranean Seas (Kasapidis et al. 2007; Kalogirou et al. 2010 and Deidun et al. 2015).

The Silver-cheeked Toadfish is the worst among other pufferfishes caught from the Eastern Mediterranean coast of the Gaza Strip (Table 2). All these pufferfishes were known to contain toxins in some or all of their tissues as declared by the Directorate General of Fisheries, Ministry of Agriculture and pointed out by Abu Amra (2018). The most severe case of these puffers, having adverse impact on human health is the Silver-cheeked Toadfish. In Egypt, which is a very close country to Palestine, Halim and Rizkalla (2011) pointed out that the species rapidly extended to Egyptian waters where it became abundant in the fish catch. They added that the species proved to be a serious hazard to consumers, causing paralysis of the mouth and limbs. Puffers include approximately 130 species worldwide within the Tetraodontidae family, among which many are found in the eastern and western Mediterranean Sea (Chamandi 2009; Kalogirou et al. 2010; Rousou et al. 2014; Enajjar et al. 2015; Farrag et al. 2015a and b; El-Haweet et al. 2016; Vella et al. 2017 and Alshawy et al. 2019). The Suez Puffer (Lagocephalus suezensis Clark \& Gohar, 1953), which is considered rare in the Mediterranean waters of the Gaza Strip, was recorded in the by-catch of other Mediterranean countries (Bilecenoglu et al. 2002; Saad 2005; Ben-Abdallah et al. 2011; El-Haweet et al. 2016). 
Table 1. Morphometric measurements for a Silver-cheeked Toadfish specimen caught from the Mediterranean waters of the Gaza city, Gaza Strip, Palestine (2019)

\begin{tabular}{lcc}
\hline Measurements & $\begin{array}{c}\text { Millimeter } \\
(\mathbf{m m})\end{array}$ & $\begin{array}{c}\text { Relative } \\
\text { proportions }\end{array}$ \\
\hline Total Length (TL) & 480 & $100.0 \% \mathrm{TL}$ \\
Fork Length (FL) & 457 & $94.7 \% \mathrm{TL}$ \\
Standard Length (SL) & 395 & $82.2 \% \mathrm{TL}$ \\
Head Length (HL) & 112 & $24.5 \% \mathrm{SL}$ \\
Body Depth (BD) & 109 & $23.9 \% \mathrm{SL}$ \\
Eye Diameter (ED) & 36 & $32.1 \% \mathrm{HL}$ \\
\hline
\end{tabular}

Table 2. Species of poisonous pufferfishes encountered at the marine ecosystem of the Gaza Strip, Palestine

\begin{tabular}{cll}
\hline \multicolumn{2}{c}{ Order: Tetraodontiformes } \\
\hline Family & \multicolumn{1}{c}{ Scientific name } & Common name \\
\hline Tetraodontidae & Lagocephalus sceleratus & Silver-cheeked \\
(Pufferfishes) & Gmelin, 1789 & Toadfish \\
& Lagocephalus spadiceus, & Half-smooth \\
& Richardson, 1845 & Golden Pufferfish \\
& Lagocephalus laevigatus, & Smooth Puffer \\
& Linnaeus, 1766 & \\
& Lagocephalus suezensis & Suez Puffer \\
& Clark \& Gohar, 1953 & \\
& Torquigener flavimaculosus, Yellow-spotted \\
& Hardy \& Randall, 1983 & Puffer \\
\hline
\end{tabular}

\section{Local naming and capture of the Silver-cheeked Toadfish}

Gaza fishermen and local people claimed that the local name of the species and its relatives of the Tetraodontidae family (Table 1) is known locally as Arnab, which means rabbit. Such a name refers to the way of removing and cleaning the skin of the fish, which resembles that of the Domestic Rabbit Oryctolagus cuniculus and the Cape Hare Lepus capensis (Mammalia: Lagomorpha) which are delicious meals for Gazans.

With regard to the capture of the species, Gaza fishermen pointed out that the sites of fisheries efforts including the by-catch of the Silver-cheeked Toadfish and other pufferfishes extended over the entire length of the Palestinian coast in the Gaza Strip from Beit Lahia north to Rafah south (a distance measuring about $42 \mathrm{~km}$ in the eastern Mediterranean). They also ensured that the species is an occasional capture of the Palestinian fisheries. It is often by-caught using all kinds of fishing gear such as gill nets, trammel nets, trawling, longlines, etc. In spite of discarding the species in the seawater, they added that the species has increased in abundance in the last couples of years. The fact that the Silver-cheeked Toadfish is commonly by-caught using different fishing gear including nets and longlines was confirmed by other studies along the coasts of Mediterranean countries (Nader et al. 2012; Farrag et al. 2015a, b; El-Haweet et al. 2016; Kosker et al. 2016).

\section{Impact of the Silver-cheeked Toadfish on fisheries and fishing gear}

Although the impact seems to be minimal in the marine ecosystem of the Gaza Strip because of its small fishing area, desertification, overexploitation, and clear fragility (MEnA 2001; Abd Rabou et al. 2007 and Abd Rabou 2013), many fishermen claimed that this invasive species has the ability to damage their fishing nets, lines and hooks by its strong teeth. They, at the same time, ensured the ability of the Silver-cheeked Toadfish to attack fishes caught in the nets and longlines and as a result, it seriously damages both fishing gear and catches. This phenomenon has also been observed in other countries such as Lebanon, Tunisia, Cyprus, Greece and other Mediterranean countries (EastMed 2010; Nader et al. 2012; Ben Souissi et al. 2014; Ünal et al. 2015 and Öndes et al. 2018). With regard to the impact of the species on the marine catch, Kalogirou et al. (2010) confirmed the destruction of nets in many Mediterranean countries including Turkey, Lebanon and Egypt due to entangling or to predation by the Silvercheeked Toadfish on already entangled fish. Kalogirou et al. (2010) added that the species can reduce local stocks of squids and octopuses through predation. Such impacts of pufferfishes on fishing gear forced fishermen in many countries to modify their fishing techniques and habits (EastMed 2010). The impacts of the species on fishing gear make it as a major nuisance to fishermen and fisheries. As a result, many Mediterranean countries have banned the fishing and trade of the species. Mitigation measures including fishing in deeper grounds, attaching the hooks to steel lines to prevent their loss to biting, and manufacturing fishing nets with stronger and more resistant material have been suggested as well (Kalogirou et al. 2010).

\section{Trade of the Silver-cheeked Toadfish in the Gaza Strip}

The author ensured that several specimens of the Silvercheeked Toadfish have been introduced surreptitiously and very cautiously among other commercial fishes to be sold at the local markets (Figure 3). Before banning the fish in early 2010s, the species was sold freely at many fish markets (Figure 4). Nowadays, there is a state of consciousness was formed by the fishermen, most of them get rid of the poisonous fishes immediately after fishing and they did not mix them with other fish to be sold at markets.

\section{Dialogue on and uncertainty of the toxicity of the Silver-cheeked Toadfish}

Although all fisheries parties of the Gaza Strip including Gaza fishermen and the Directorate General of Fisheries, Ministry of Agriculture confirmed the toxicity of the Silver-cheeked Toadfish and other pufferfishes for possible consumers, others claimed that they ate fishes belonging to pufferfish family and did not experience any poisoning features. More recently, many fishermen met by the author confirmed their eating to larger pufferfishes including the Silver-cheeked Toadfish after cleaning the fishes from their skins and all poisonous viscera. One added that the heads of the Silver-cheeked Toadfish were used to make soaps. In light of these opinions, many scientific interpretations should be considered. 


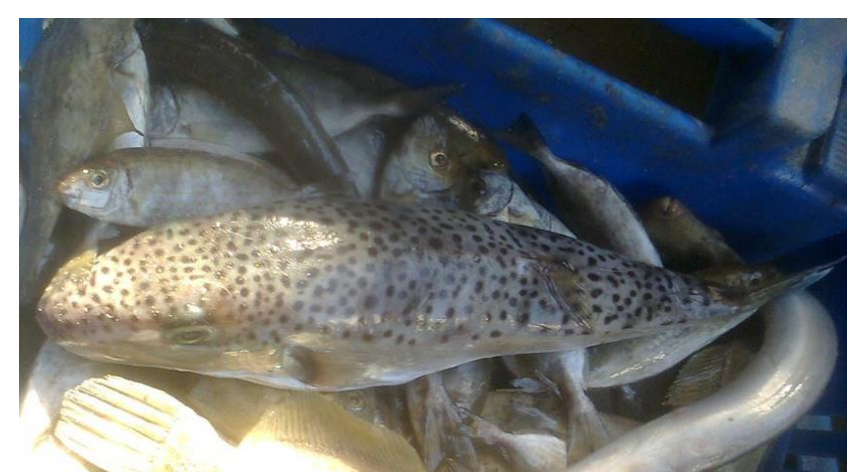

Figure 3: The Silver-cheeked Toadfish was sometimes displayed among other bony fishes for sale in a fish market in North Gaza, Palestine

One way to interpret such claims is that the most caught individuals of the Silver-cheeked Toadfish and other pufferfishes in the Gaza Strip have small sizes (Personal Observations). In this regard, many studies showed a significant positive correlation between toxicity levels and size of pufferfishes. Katikou et al. (2009) pointed out that the toxicity levels of individuals smaller than $16 \mathrm{~cm}$ in length are not lethal to humans. Several studies supported such results and pointed out that younger specimens contain low amount of TTX or even no toxin at all (Sabrah et al. 2006; Saoudiet al. 2008; Katikou et al. 2009; Simon et al. 2009; Ali et al. 2011). By contrast, larger specimens are known to be poisonous and lethal to humans (Katikou et al. 2009). This means that the Silver-cheeked Toadfish accumulates TTX as a biological defense agent with time as it matures. Accordingly, the larger samples seem to be more poisonous than smaller ones (Ahasan et al. 2004; Noguchi and Arakawa 2008; Saoudi et al. 2008; Arakawa et al. 2010 and Rambla-Alegre et al. 2017). Another way to interpret such surprising results is the fact that TTX of the Silver-cheeked Toadfish concentrates mainly in the gonads and liver and to a lesser extent in the skin, muscles and other organs. This was confirmed in an Egyptian study conducted by Ali et al. (2011) who revealed that the toxicity of the Silver-cheeked Toadfish showed the highest value for ovaries, intestine, and liver, while the muscle and skin had lowest toxicities. Locally, the gonads, skin, liver and even the head itself are commonly not eaten and they are thrown before cooking. This may contribute to lower the risks of poisoning by consumers. In contrast, such gonads and livers are considered vey delicious in certain areas of the world, and their eating by some people causes hospitalization and even deaths (Arakawa et al. 2010; Nader et al. 2012 and Tamele et al. 2019).

\section{Local cases of hospitalizations because of TTX intoxication}

In spite of the previous dialogue, several cases of hospitalization have been reported in the Gaza Strip after consumption of the Silver-cheeked Toadfish as pointed out by the Directorate General of Fisheries, Ministry of Agriculture and many fishermen and local people. In contrast, death cases following the consumption of the

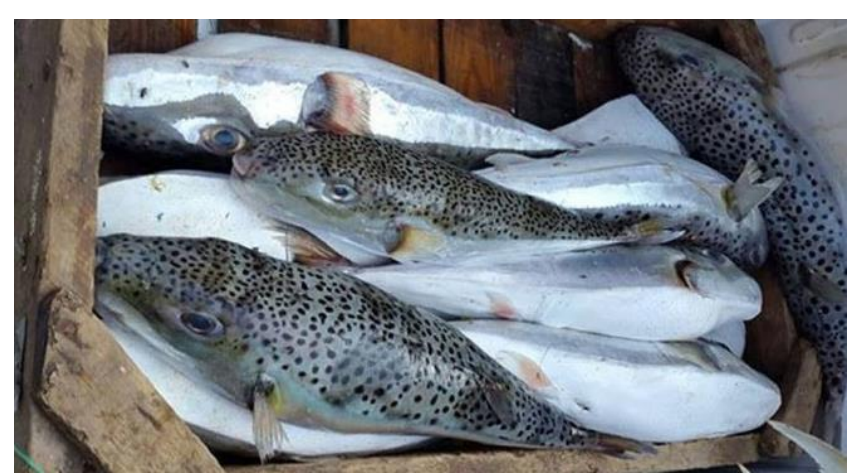

Figure 4: Free trade of the Silver-cheeked Toadfish before its banning in the Gaza Strip, Palestine in early 2010s

Silver-cheeked Toadfish have never been stated to happen in the Gaza Strip as claimed by both fishermen and people. A lot of studies pointed out cases of hospitalization and even fatal intoxications related to the consumption of the Silver-cheeked Toadfish worldwide including the Mediterranean countries (Zaki 2004; Bentur et al. 2008; Chamandi et al. 2009; Katikou et al. 2009; Kalogirou et al. 2010; Nader et al. 2012; Beköz et al. 2013; Ben Souissi et al. 2014; Kosker et al. 2016 and Ünal and GöncüoğluBodur 2018). In spite of these health risks, the Silvercheeked Toadfish was encountered to be illegally sold along the Mediterranean coasts of Turkey, Lebanon, Egypt, and many other countries as stated by Aydin (2011) and Halim and Rizkalla (2011). According to Aydin (2011), the severity of the intoxication depends much on the amount of TTX ingested, in addition to the age, health status, and sensitivity of the person ingesting TTX. Arakawa et al. (2010) pointed out that there is no fundamental treatment focusing on eliminating the toxin completely from the body, and no antidotes or antitoxins exist for TTX.

Even in Japan and its neighboring countries, where pufferfishes including the Silver-cheeked Toadfish are highly consumed, still cases of intoxication and deaths occur because the fishes in question are prepared sometimes by unlicensed cooks or uncertified handlers (Ahasan 2004 and Chamandi 2009). Based on the Japanese regulations, which are considered as the most elaborate regarding pufferfish species consumption, the Silvercheeked Toadfish is labeled as a non-edible fish due to its high toxicity (Nader et al. 2012).

\section{Symptoms of TTX intoxication in the Gaza Strip}

Poisoning after eating the Silver-cheeked Toadfish containing TTX is widespread worldwide. In the Gaza Strip, many people were poisoned and hospitalized. They were said to show many symptoms of poisoning including nausea and vomiting, dizziness, headache, abdominal pain, perioral paraesthesia, and tingling over the entire body. More or less of these symptoms were encountered among people after consuming pufferfishes containing TTX as pointed out by many authors (Bentur et al. 2008; Islam et al. 2011 and Kheifets et al. 2012). In Israel, Eisenman et al. (2008) pointed out that a total of 13 cases of TTX 
poisoning were registered by Israel Poison Information Center in December 2008 due to the consumption of the Silver-cheeked Toadfish. The symptoms of poisoning were more or less similar to those revealed by Gaza poisoning cases. The symptoms included perioral paraesthesia, tingling over the entire body, nausea and vomiting, dizziness, headache, abdominal pain, and muscular paralysis of the limbs. Although a few persons died from rapidly developing respiratory arrest in many countries (Bentur et al. 2008), death was not developed in the Gaza Strip after TTX intoxication as previously mentioned.

\section{Local efforts discussing the toxicity of the Silver- cheeked Toadfish}

In spite of the toxicity of the Silver-cheeked Toadfish, many awareness campaigns have been carried out mainly by the Directorate General of Fisheries, Ministry of Agriculture; in order warn fishermen and local people from the health risks associated with the consumption of pufferfishes in general and the Silver-cheeked Toadfish in particular. The author himself participated in a workshop dealing with such events on October 20, 2014. Moreover, inspectors and observers from the Directorate General of Fisheries, Ministry of National Economy, Ministry of Health and marine police usually visit fish markets to prevent the sale of poisonous pufferfishes to consumers. At the same time, the inspectors warn against the dangers of pufferfishes, especially the Silver-cheeked Toadfish fish on the marine environment and the public health.

The author himself held several scientific meetings with news and radio sites to warn against handling and eating the exotic Silver-cheeked Toadfish because of its health risks. Additionally, the author wrote some short essays and Facebook posts aimed at showing the dangers of the Silvercheeked Toadfish on the marine ecosystem and public health and disseminating them to some local websites. These public awareness campaigns launched by the different parties form a good step in establishing an early warning system against pufferfishes in the Gaza Strip. According to Nader et al. (2012) and Azzurro et al. (2016a and $b$ ), public awareness campaigns are very essential to prevent the ecological and health impacts of the Silvercheeked Toadfish. In a developed country like Italy, Azzurro et al. (2016b) pointed out that escalating public campaigns were set to inform Italian citizens on the health risks associated with TTX intoxication due to consumption of the Silver-cheeked Toadfish. Both news media and local communities responded rapidly to the initiative generating an increasing flow of information. In Spain, the number of web pages bearing information on the Silver-cheeked Toadfish jumped from 73 in 2015 to 1220 in 2016 (Azzurro et al. 2016a). In Tunisia, the Tunisian Ministry of Agriculture was found to conduct information campaigns regarding the Silver-cheeked Toadfish. The Ministry publishes posters advertising the toxicity of the species, written in Arabic language. The poster bans the landing, marketing, and consumption of this species. It explains to the public that the TTX is very concentrated in the gonads and liver of the fish and that it is resistant to cooking (Ben Souissi et al. 2014).
In conclusion, the Silver-cheeked Toadfish is considered a highly toxic species and therefore it is not targeted for human consumption in the Gaza Strip as the case in other Mediterranean and non-Mediterranean countries. With the exception of some violations, the Silver-cheeked Toadfish along with other pufferfishes are not landed on the local markets as a commercial species and do not have any economic value as stated by the Directorate General of Fisheries, Ministry of Agriculture. The need for continuous public information campaigns dealing with the ecological, socio-economic and health risks imposed by the Silver-cheeked Toadfish and the development of an early warning system of its spread is very essential. The species poses threats on several levels in the Eastern Mediterranean countries and therefore potential solutions to the problem should be explored.

\section{ACKNOWLEDGEMENTS}

The author would like to thank the staff of the Directorate General of Fisheries Resources, Ministry of Agriculture, and all Gaza fishermen who provided the current study with the valuable information needed.

\section{REFERENCES}

Abd Rabou AN, Yassin MM, Saqr TM, Madi AS, El-Mabhouh FA, Abu Nada FM, Al-Masri MK, Doulah MH, Al-Haj Ahmad MM. 2007. Threats facing the marine environment and fishing in the Gaza Strip: Field and literature study. Theme XII: Environmental Design Trends and Pollution Control, The 2nd International Engineering Conference on Construction and Development (IECCD-II), Islamic University of Gaza, Gaza Strip, Palestine, September 3-4, 2007, 11-31.

Abd Rabou AN. 2013. Priorities of scientific research in the fields of marine environment and fishery resources in the Gaza Strip Palestine. Priorities of Scientific Research in Palestine: Towards a National Directory of Scientific Research, March 25-26, 2013, Scientific Research Affairs, Islamic University of Gaza, Gaza Strip, Palestine.

Abdul Malak D, Livingstone SR, Pollard D, Polidoro BA, Cuttelod A, Bariche M, Bilecenoglu M, Carpenter KE, Collette BB, Francour P, Goren M, Kara MH, Massutí E, Papaconstantinou C, Tunesi L. 2011. Overview of the conservation status of the marine fishes of the Mediterranean Sea. IUCN, Gland, Switzerland and Malaga, Spain.

Abu Amra HE. 2018. A survey of marine bony fishes of the Gaza Strip, Palestine. [Thesis], Department of Biology, Islamic University of Gaza, Gaza Strip, Palestine.

Ahasan HA, Al-Mamun AA, Karim SR, Bakar MA, Gazi EA, Bala, CS. 2004. Paralytic complications of Puffer Fish (tetrodotoxin) poisoning. Singap Med J 45 (2): 73-74.

Akyol O, Ünal V, Ceyhan T, Bilecenoglu M. 2005. First confirmed record of Lagocephalus sceleratus (Gmelin, 1789) in the Mediterranean Sea. J Fish Biol 66 (4): 1183-1186.

Akyol O, Ünal V. 2017. Long journey of Lagocephalus sceleratus (Gmelin, 1789) throughout the Mediterranean Sea. Nat Eng Sci (Suppl) 2 (3): 41-47.

Ali AA, El-Ganainy AA, Ahmed AI, Ahmed MI. 2015. Reproductive biology of Lagocephalus sceleratus in Mediterranean and Red Seas, Egypt. Egypt J Aquat Biol Fish 19 (4): 103-114.

Ali AE, Gomaa MN, Othman HM. 2011. Toxicological studies on pufferfishes, Lagocephalus sceleratus and Amblyrhynchotes hypeslogenion in Suez Gulf, Red Sea, Egypt. Egypt J Aquat Res 37 (2): 123-130.

Alshawy FA, Ibrahim A, Hussein C, Lahlah, M. 2019. First record of the oceanic puffer Lagocephalus lagocephalus (Linnaeus, 1758) from the 
Syrian marine waters (Eastern Mediterranean). Mar Biodivers Rec 12 (11): $1-4$.

Arakawa O, Hwang DF, Taniyama S, Takatani T. 2010. Toxins of Pufferfish that cause human intoxications. In Ishimatsu A, Lie HJ. (eds) Coastal Environmental and Ecosystem Issues of the East China Sea, Terrapub and Nagasaki University: Tokyo, Japan, 2010.

Aydin M. 2011. Growth, reproduction and diet of Silver-cheeked Toadfish (Lagocephalus sceleratus Gmelin, 1789) from Turkey's Mediterranean Sea Coast. Turkish J Fish Aquat Sci 11: 589-596.

Azzurro E, Allué M, Andaloro F, Bariche M, Broglio E, Castriota L, del Rio V, Falautano M, Lombarte A. 2016a. Do not eat Lagocephalus sceleratus: A transnational alert through the western Mediterranean. 41st CIESM Congress Proceedings: 434.

Azzurro E, Castriota L, Falautano M, Bariche M, Broglio E, Andaloro F. 2016b. New records of the Silver-cheeked Toadfish Lagocephalus sceleratus (Gmelin, 1789) in the Tyrrhenian and Ionian Seas: Early detection and participatory monitoring in practice. BioInvasions Rec 5 (4): 295-299.

Azzurro E, Castriota L, Falautano M, Giardina F, Andaloro F. 2014. The Silver-cheeked Toadfish Lagocephalus sceleratus (Gmelin, 1789) reaches Italian waters. J Appl Ichthyol 30 (5): 1050-1052.

Bariche M. 2012. Field identification guide to the living marine resources of the Eastern and Southern Mediterranean. Food and Agriculture Organization of the United Nations (FAO), Rome.

Başusta A, Başusta N, Özer E.I. 2013. Length-weight relationship of two pufferfishes, Lagocephalus sceleratus and Lagocephalus spadiceus, from Iskenderun Bay, northeastern Mediterranean, Turkey. Pak J Zool 45 (4): 1047-1051.

Beköz AB, Beköz S, Yilmaz E, Tüzün S, Beköz U. 2013. Consequences of the increasing prevalence of the poisonous Lagocephalus sceleratus in southern Turkey. Emerg Med J 30 (11): 954-955.

Ben Souissi J, Rifi M, Ghanem R, Ghozzi L, Boughedir W, Azzurro E. 2014. Lagocephalus sceleratus (Gmelin, 1789) expands through the African coasts towards the Western Mediterranean Sea: A call for awareness. Manag Biol Invasions 5 (4): 357-362.

Ben-Abdallah BA, Al-Turky A, Nafti A, Shakman E. 2011. A new record of a Lessepsian fish, Lagocephalus suezensis (Actinopterygii: Tetraodontidae), in the south Mediterranean (Libyan coast). Acta Ichthyologica et Piscatoria 41 (1): 71-72.

Bentur Y, Ashkar J, Lurie Y, Levy Y, Azzam Z, Litmanovich M, Gurevych B, Golani D, Eisenman A. 2008. Lessepsian migration and tetrodotoxin poisoning due to Lagocephalus sceleratus in the eastern Mediterranean. Toxicon 52 (8): 964-968.

Bilecenoglu M, Kaya M, Akalin S. 2006. Range expansion of Silverstripe Blaasop, Lagocephalus sceleratus (Gmelin, 1789), to the Northern Agean Sea. Aquat Invasions 1 (4): 289-291.

Bilecenoglu M, Taskavak E, Kunt KB. 2002. Range extension of three Lessepsian migrant fish (Fistularia commersonii, Sphyraena flavicauda, and Lagocephalus suezensis) in the Mediterranean Sea. J Mar Biol Assoc UK 82 (3): 525-526.

Carbonara P, Kolitari J, Durović M, Gaudio P, Ikica Z, Kroqi G. Milone N, Spedicato MT. 2017. The presence of Tetraodontidae species in the Central Mediterranean: An update from the southern Adriatic Sea. Acta Adriat 58 (2): 325-338.

Cevik C, Toklu B, Sarihan E. 2002. The impact of the Red Sea species (Lessepsian) on the Mediterranean Sea. In: Bayram Öztürk and Nuri Basusta (eds). Workshop on Lessepsian migration, 20-21 July 2002, Gökceada, Turkey.

Chamandi SC, Kallab K, Mattar H, Nader E. 2009. Human Poisoning after ingestion of Puffer Fish caught from Mediterranean Sea. Case Report - USEK Medical School, Lebanon.

Deidun A, Fenech-Farrugia A, Castriota L, Falautano M, Azzurro E, Andaloro F. 2015. First record of the Silver-cheeked Toadfish Lagocephalus sceleratus (Gmelin, 1789) from Malta. BioInvasions Rec 4 (2): 139-142.

Dulčić J, Dragičević B, Antolović N, Sulić-Šprem J, Kožul V, Grgičević R. 2014. Additional records of Lobotes surinamensis, Caranx crysos, Enchelycore anatina, and Lagocephalus sceleratus (Actinopterygii) in the Adriatic Sea. Acta Ichthyologica et Piscatoria 44 (1): 71-74.

EastMed. 2010. Report of the Sub-Regional Technical meeting on the Lessepsian migration and its impact on Eastern Mediterranean fishery. GCP/INT/041/EC - GRE - ITA/TD-04.

Eisenman A, Rusetski V, Sharivker D, Yona Z, Golani D. 2008. An odd pilgrim in the Holy Land. Am J Emerg Med 26 (3): 383.e3-383.e6.
El-Haweet AAK, Farrag MMS, Akel EA, Moustafa MA. 2016. Puffer fishes catch in the Egyptian Mediterranean coast: The challenged invaders. Intl J Ecotoxicol Ecobiol 1 (1): 13-19.

Enajjar S, Hamida NB, Saadaoui A, Bradaï MN. 2015. New data on pufferfish species (Osteichthyes: Tetraodontidae) occurring in Tunisian waters (central Mediterranean Sea). Mar Life 18: 33-41.

Encarnação J, Morais P, Baptista V, Cruz J, Teodósio MA. 2019. New evidence of marine fauna tropicalization off the Southwestern Iberian Peninsula (Southwest Europe). Diversity 11 (48): 1-11.

Farrag MMS, El-Haweet AAK, Akel EKA, Moustafa MA. 2015a. Occurrence of pufferfishes (Tetraodontidae) in the eastern Mediterranean, Egyptian coast: Filling in the gap. BioInvasions Rec 5 (1): 47-54.

Farrag MMS, El-Haweet AAK, El-Sayed KA, Akel EKA, Moustafa MA. 2015b. Stock status of Puffer Fish Lagocephalus sceleratus (Gmelin, 1789) along the Egyptian coast, Eastern Mediterranean Sea. Am J Life Sci 3 (1): 83-93.

Golani D, Azzurro E. 2007. Genetic bottlenecks and successful biological invasions: The case of recent Lessepsian migrants. Biol Lett 3 (5): 541-545.

Golani D, Levy Y. 2005. New records and rare occurrences of fish species from the Mediterranean coast of Israel. Zool Middle East 36 (1): 2732.

Golani D. 1996. The marine ichthyofauna of the eastern Levant: History, inventory and characterization. Israel J Zool 42 (1): 15-55.

Halim Y, Rizkalla S. 2011. Aliens in Egyptian Mediterranean waters: A checklist of Erythrean fish with new records. Mediterr Mar Sci 12 (2): 479-490

Irmak E, Altınağaç U. 2015. First record of an invasive Lessepsian migrant, Lagocephalus sceleratus (Actinopterygii: Tetradontiformes: Tetraodontidae), in the Sea of Marmara. Acta Ichthyologica et Piscatoria, 45 (4): 433-435.

Islam QT, Razzak MA, Islam MA, et al. 2011. Pufferfish poisoning in Bangladesh: clinical and toxicological results from large outbreaks in 2008. Trans R Soc Trop Med Hyg 105 (2): 74-80.

Jribi I, Bradai MN. 2012. First record of the Lessepsian migrant species Lagocephalus sceleratus (Gmelin, 1789) (Actinopterygii: Tetraodontidae) in the Central Mediterranean. Bioinvasions Rec 1 (1): 49-52.

Kalogirou S, Corsini-Foka M, Sioulas A, Wennhage H, Pihl L. 2010. Diversity, structure and function of fish assemblages associated with Posidonia oceanica beds in an area of the Eastern Mediterranean Sea and the role of non-indigenous species. J Fish Biol 77 (10): 23382351.

Kalogirou S. 2013. Ecological characteristics of the invasive Puffer Fish Lagocephalus sceleratus (Gmelin, 1789) in Rhodes, Eastern Mediterranean Sea: A case study. Mediterr Mar Sci 14 (2): 251-260.

Kara MH, Ben Lamine E, Francour P. 2015. Range expansion of an invasive pufferfish, Lagocephalus sceleratus (Actinopterygii: Tetradontiformes: Tetraodontidae), to the south-western Mediterranean. Acta Ichthyologica et Piscatoria 45 (1): 103-108.

Kasapidis P, Peristeraki P, Tserpes G, Magoulas A. 2007. First record of the Lessepsian migrant Lagocephalus sceleratus (Gmelin 1789) (Osteichthyes: Tetraodontidae) in the Cretan Sea (Aegean, Greece). Aquat Invasions 2 (1): 71-73.

Katikou P, Georgantelis D, Sinouris N, Petsi A, Fotaras T. 2009. First report on toxicity assessment of the Lessepsian migrant pufferfish Lagocephalus sceleratus (Gmelin, 1789) from European waters (Aegean Sea, Greece). Toxicon 54 (1): 50-55.

Kheifets J, Rozhavsky B, Solomonovich ZG, Marianna R, Soroksky A. 2012. Severe Tetrodotoxin poisoning after consumption of Lagocephalus sceleratus (Pufferfish, Fugu) fished in Mediterranean Sea: Case report, Treated with Cholinesterase Inhibitor. Case Reports in Critical Care, Hindawi Publishing Corporation, London.

Kleitou P, Kalogirou S, Marmara D, Giovos I. 2018. Coryphaena hippurus: A potential predator of Lagocephalus sceleratus in the Mediterranean Sea. Intl J Fish Aquat Stud 6 (3): 93-95

Kosker AR, Özogul F, Durmus M, Ucar Y, Ayas D, Regenstein JM, Özogul Y. 2016. Tetrodotoxin levels in pufferfish (Lagocephalus sceleratus) caught in the Northeastern Mediterranean Sea. Food Chem 210: 332-337.

MEnA. 2001. Gaza Coastal and marine environmental protection and management action plan. Ministry of Environmental Affairs (MEnA), Palestinian National Authority, Gaza City, Palestine. 
Milazzo M, Azzurro E, Badalamenti F. 2012. On the occurrence of the Silverstripe Blaasop Lagocephalus sceleratus (Gmelin, 1789) along the Libyan coast. BioInvasions Rec 1 (2): 125-127.

Nader M, Indary S, Boustany L. 2012. The Puffer Fish Lagocephalus sceleratus (Gmelin, 1789) in the Eastern Mediterranean. EastMed Technical Documents 10, FAO EastMed, Athens.

Noguchi T, Arakawa O. 2008. Tetrodotoxin: Distribution and accumulation in aquatic organisms and cases of human intoxication Mar Drug 6 (2): 220-242.

Öndes F, Ünal V, Özbilgin Y, Deval C, Turan C. 2018. By-catch and monetary loss of pufferfish in Turkey, the Eastern Mediterranean. Ege J Fish Aquat Sci, 35 (4): 361-372.

Peristeraki P, Lazarakis G, Skarvelis C, Georgiadis M, Tserpes G. 2006 Additional records on the occurrence of alien fish species in the eastern Mediterranean Sea. Mediterr Mar Sci 7 (2): 61-66.

Rambla-Alegre M, Reverté L, Del Río V, de la Iglesia P, Palacios O, Flores C, Caixach J, Campbell K, Elliott C.T, Izquierdo-Muñoz A, Diogène J. 2017. Evaluation of tetrodotoxins in pufferfish caught along the Mediterranean coast of Spain: Toxin profile of Lagocephalus sceleratus. Environ Res, 158: 1-6.

Rilov G, Galil B. 2009. Marine bioinvasions in the Mediterranean Sea History, distribution and ecology. In: Rilov G, Crooks J A. (eds) Biological Invasions in Marine Ecosystems. Springer, Berlin.

Rousou M, Ganias K, Kletou D, Loucaides A, Tsinganis M. 2014 Maturity of the pufferfish Lagocephalus sceleratus in the southeastern Mediterranean Sea. Sex Early Dev Aquat Org, 1: 35-44.

Saad AA. 2005. Check-list of bony fish collected from the coast of Syria Turkish J Fish Aquat Sci 5 (2): 99-106.

Sabrah, M.M, El-Ganainy, A.A, Zaky, M.A. 2006. Biology and toxicity of the pufferfish Lagocephalus sceleratus (Gmelin, 1789) from the Gulf of Suez. Egypt J Aquat Res 32 (1): 283-297.

Saoudi M, Abdelmouleh A, Kammoun W, Ellouze F, Jamoussi K, El-Feki A. 2008. Toxicity assessment of the Pufferfish Lagocephalus lagocephalus from the Tunisian coast. Comptes Rendus Biol 331 (8): 611-616.

Shaheen AL. 2016. Assessment of pisciculture status in the Gaza Strip. [Thesis]. Department of Biological Sciences, Al-Azhar University, Gaza, Palestine.

Simon KD, Mazlan AG, Usup G. 2009. Toxicity of Puffer Fishes (Lagocephalus wheeleri Abe, Tabeta and Kitahama, 1984 and Lagocephalus sceleratus Gmelin, 1789) from the east coast waters of Peninsular Malaysia. J Biol Sci 9 (5): 482-487.

Sims JK, Ostman DC. 1986. Puffer Fish poisoning: emergency diagnosis and management of mild human tetrodotoxication. Ann Emerg Med 15 (9): 1094-1098
Sulić-Šprem, J, Dobroslavić, T, Kožul, V, Kuzman, A, Dulčić, J. 2014 First record of Lagocephalus sceleratus in the Adriatic Sea (Croatian coast): A Lessepsian migrant. Cybium 38 (2): 147-148.

Tamele IJ, Silva M, Vasconcelos V. 2019. The incidence of Tetrodotoxin and its analogs in the Indian Ocean and the Red Sea. Mar Drug 17 (28): 1-16.

Tiralongo F, Tibullo D. 2014. Lagocephalus sceleratus (Gmelin, 1789), (Pisces: Tetraodontidae) reaches the Italian Ionian Sea, pp. 203-204. In: Kapiris K. et al. (eds). New Mediterranean Marine Biodiversity Records (April 2014). Mediterr Mar Sci 15 (1): 198-212.

Torcu-Koç H, Erdoğan Z, Üstün F. 2011. Occurrence of the Lessepsian migrant, Lagocephalus sceleratus (Gmelin 1789) (Osteichthyes: Tetraodontidae), in İskenderun Bay (north-eastern Mediterranean, Turkey). J Appl Ichthyol 27 (1): 148-149.

Tunçer S, Önal U. 2014. Further range expansion of the silver-cheeked toadfish, Lagocephalus sceleratus (Teleostei: Tetraodontidae), in Turkish waters. Mediterr Mar Sci 15 (3): 675-695.

Türker-Cakır D, Yarmaz A, Balaban C. 2009. A new record of Lagocephalus sceleratus (Gmelin 1789) confirming a further range extension into the northern Aegean Sea. J Appl Ichthyol 25 (5): 606607.

Ünal V, Göncüoğlu H, Durgun D, Tosunoğlu, Z, Deval, C, Turan, C. 2015. Silver-cheeked Toadfish, Lagocephalus sceleratus (Actinopterygii: Tetradontiformes: Tetraodontidae), causes substantial economic losses in Turkish Mediterranean coast: A call for decision-makers. Acta Ichthyologica et Piscatoria 45 (3): 231-237.

Ünal V, Göncüoğlu-Bodur H. 2017. The socio-economic impacts of the Silver-cheeked Toadfish on small-scale fishers: A comparative study from the Turkish coast. Ege J Fish Aquat Sci 34 (2): 119-127.

Ünal V, Göncüoğlu-Bodur H. 2018. Impacts of pufferfish on human activities in Turkey, Eastern Mediterranean: Special emphasis on Lagocephalus sceleratus, pp. 149-165 in CIESM Workshop Monograph n ${ }^{\circ} 50$ [F. Briand, Ed.] CIESM Publisher, Monaco.

Vella A, Vella N, Karakulak FS, Oray I. 2017. DNA barcoding of Tetraodontidae species from the Mediterranean Sea: Filling knowledge gaps for improved taxonomic accuracy. Genet Aquat Org 1: 61-69.

Yaglioglu D, Turan C, Erguden D, Gurlek M. 2011. Range expansion of Silverstripe, Lagocephalus sceleratus (Gmelin, 1789), to the northeastern Mediterranean Sea. Biharean Biol 5 (2): 159-161.

Zaki AM. 2004. Tetrodotoxin poisoning associated with eating puffer fish in Suez City (Egypt). In: First International Conference on Natural Toxins, October 6 University, 18-19 December 2004, Egypt. 